\title{
QUALITY ASSESSMENT OF SACHET AND BOTTLED WATER SOLDIN GBOKO, BENUE STATE, NIGERIA.
}

\author{
G. D. Akpen ${ }^{1,}{ }^{*}$, I. S. Kpoghol ${ }^{2}$ and L. A. Oparaku ${ }^{3}$ \\ 1,2, Department of Civil EngineERING, University of Agriculture, MAKURdi, BENUE STATE. NiGERIA

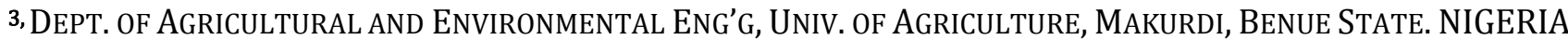 \\ Email addresses:1deliakpen@yahoo.com, ${ }^{2}$ soniaiwuese@gmail.com, 3 alimonu2013@gmail.com
}

\begin{abstract}
The quality of selected sachet and bottled water produced and sold within Gboko town, Benue State was investigated to determine their Shelf life. Eight brands of sachet water and four brands of bottled water samples were collected from different manufacturers within 24 hours and stored at ambient temperature. Sub-samples were drawn from the stock samples at intervals of three weeks up to a period of 15 weeks and subjected to physical, chemical and microbial examination. Results for physical and chemical analysis revealed that all the samples examined were wholesome by the $12^{\text {th }}$ week of study except, samples K4and B4 (Wishden sachet and bottled water) which had iron contents of $0.50 \mathrm{mg} / \mathrm{L}$ and $0.53 \mathrm{mg} / \mathrm{L}$ respectively which were above WHO Standard value of $0.30 \mathrm{mg} / \mathrm{L}$. Total and Escherichia coliforms appeared in all sachet water samples and three bottled water samples analyzed within the first 6 weeks but were no longer detected in any of the samples from the $12^{\text {th }}$ week to the end of the investigation period. The highest total coliform of $21 \mathrm{MPN} / 100 \mathrm{~mL}$ and Escherichia coli of $17 \mathrm{cfu} / 100 \mathrm{~mL}$ were recorded on the first day of production of sachet water. It was concluded that some sachet water products consumed in Gboko were not safe for drinking within the first 12 weeks of production. It was recommended that sachet and bottled water produced and consumed in Gboko can be used from the 3 and 12 weeks after production respectively up to 15 weeks. However, there is need to investigate the shelf life beyond 15 weeks to determine the actual shelf life which may be more than 15 weeks.
\end{abstract}

Keywords: Physico-chemical Quality, Coliforms, Gboko, Sachet and Bottled Water, Shelf life.

\section{INTRODUCTION}

Water is an essential part of human nutrition, both directly as drinking water or indirectly as constituent of food. In addition to other applications in daily life, water is not only essential for life; it also remains the most important medium of illness and infant mortality in many developing countries and even in technologically more advanced countries [1]. It is also a key parameter influencing survival and growth of microorganisms in food and other microbial environments.

The need to define the quality of water has developed with the increasing demand for water which is suitable for specific uses and conforms to desired quality [2]. Although water quality and water quantity are inextricably linked, water quality deserves special attention because of its implications on public health and quality of life [3]. Good quality drinking water is not always readily available to man. For instance, high counts of coliform bacteria and elevated levels of zinc, lead, iron, calcium and manganese were observed in some drinking water samples in Ibeno Local Government Area of Akwa Ibom State, Nigeria [4]. Similarly, [5] reported high levels of zinc and iron in public taps and boreholes in a rural community in Kwara State, Nigeria. Unavailability of good quality drinking water is well spread and has serious health implications to man. According to [6], 80\% of all diseases and over $30 \%$ of deaths are related to drinking water in developing nations of the world.

Different researchers have tried to assess sachet and bottled water quality in Nigeria. The prevalence of bacteria in packaged sachet water sold in Nnewi, South East Nigeria was studied by [7]. The prevalence of bacteria isolated from the analyzed samples was Escherichia coli (36\%), Streptococcus faecalis (19.4\%), Klebsiella pneumonia (19.4\%) and Staphylococcus aureus (25\%). In general, both total coliform count and faecal coliform count were above the acceptable limits in some of the samples analyzed.

\footnotetext{
* Corresponding author, tel: +234- $703-904-9051$
} 
The chemical and bacteriological quality of packaged water sold in Ibadan, the capital of Oyo State was assessed by [8]. They reported that while the physical parameters were within WHO limits for drinking water quality, $30 \%$ of the samples showed rather poor chemical quality. The dominant bacteria isolated were Websiellasp, Streptococcus faecalis and Pseudomonas aeruginosa. The quality of sachet water consumed in Kano metropolis was investigated by [7]. The concentrations of metals ( $\mathrm{Zn}, \mathrm{Pb}, \mathrm{Fe}$, and $\mathrm{Cu}$ ), conductivity, dissolved solids and hardness were within the WHO permissible limits. However, some of the $\mathrm{pH}$ values were above the WHO threshold limits.

The effect of storage on the quality of sachet water produced within Port Harcourt metropolis, Nigeria was investigated by [10]. They reported that $60 \%$ of the brands analyzed met the WHO limit for drinking when stored at ambient temperature within four week period. However, storage beyond this period led to diminished aesthetic quality of sachet water and increased proliferation of bacteria to a level deleterious to human health. A study by [11] on the microbiological quality of sachet water vended in Ondo state, Nigeria revealed that, some of the samples were unsafe for human consumption due to the presence of Escherichia coli (E.coli). Other bacteria encountered in the water samples included Enterobacteraegenes, Staphylococcus aureus and Streptococcus faecalis.

The health and socio-economic implication of sachet water in Ibadan Nigeria were assessed by [12]. They reported that the physical parameters were within the WHO limits for drinking water quality, except for $\mathrm{pH}$. Some chemical parameters were also within the WHO limits. However, aluminum, fluoride and cyanide were not within the WHO limits. Bacteriological analysis showed that 5 or $6.4 \%$ of the samples tested fielded bacterial growth. Bacterial isolated included; Klibsiellasp, Streptococcus faecalis, and Pseudomonas aeruginosa. The quality of packaged water in Uyo metropolis, south eastern Nigeria was assessed by [13]. All the samples tested gave negative results for the bacteria species investigated, implying that there was no fecal contamination of the samples. However, chemical constituents such as ammonia had concentrations above acceptable limits in some samples. On the other hand, [14] reported that most physic-chemical parameters of sachet water in Zaria, Nigeria conform to the both World Health Organization (WHO) and Nigerian Standards (NIS) permissible limits for drinking water. While $100 \%$ of the sachet water samples did not conform to the WHO standards with respect to microbial quality.
This packaged water is relatively affordable and convenient and has increasingly become popular. The need to investigate the quality of packaged water therefore becomes imperative. Thus, this research is set up to investigate the quality of packaged water produced and sold in Gboko town with a view to determine the Shelf life.

\section{MATERIALS AND METHODS}

\subsection{Area of Study}

Gboko town located in the central area of Benue State, Nigeria, is the headquarters of Gboko Local Government Area and the Tiv nation. It is located on longitude9 $9^{\circ} 18^{\prime \prime}$ East and latitude $7^{\circ} 19^{\prime} 30^{\prime \prime}$ North. The town has a total area of about $1835 \mathrm{~km}^{2}$ and population of about 361,325 based on the 2006 national population census. The average rainfall of about $1400 \mathrm{~mm}$ annually and temperature of about $22^{\circ} \mathrm{C}$ $38^{\circ} \mathrm{C}$ are experienced in the area. The town is also divided into four parts; Gboko South, Gboko North, Gboko East and Gboko West.

\subsection{Sample Collection}

Eight different brands of 50cL sachet water and 4 different brands of $75 \mathrm{cL}$ bottled water samples with National Agency for Food and Drug Administration and Control(NAFDAC) certification were purchased from the study area. The samples were labeled as shown in Table 1.

Table 1: Samples of water collected

\begin{tabular}{ll}
\hline Sample & Source \\
\hline K1 & Barna Sachet Water \\
K3 & Fresh life Sachet Water \\
K4 & GTM Sachet Water \\
K5 & Wishden Sachet Water \\
K6 & Cool Sachet water \\
K7 & Paulest Sachet Water \\
K8 & Desire Sachet Water \\
B1 & Galens Sachet Water \\
B2 & Barna Bottled Water \\
B3 & Fresh Life Bottled Water \\
B4 & GTM Bottled Water \\
\hline
\end{tabular}

Two bags of each brand of sachet water containing twenty sachets each and 2 crates of each brand of bottled water containing twelve bottles each were procured at different prices within 24 hours of production and taken to Benue State Water Board Laboratory, Makurdi for analyses. A total of 168 samples from a pool of 320 samples of sachet water 
and 84 samples out of the 96 samples of bottled water were used for the analyses. The samples were stored at room temperature. The physico-chemical and microbial quality of the water samples were determined at intervals of three weeks up to a period of 15 consecutive weeks.

\subsection{Water Quality Analyses}

\subsubsection{Determination of Turbidity: Procedure}

This was determined using a portable turbidity meter (Model: TN-100/T-100 produced by EUTECH Company) according to standard methods as described in the manual. The meter was calibrated by standardizing with distilled water and the sample placed inside the cell holder. The read/enter key was then pressed and the value of turbidity read directly in NTU. The test was performed twice on each sample and average values recorded.

\subsubsection{Determination of suspended solids (SS)}

The concentration of suspended solids was determined using direct reading spectrophotometer (DR/2000) from HACH Company, according to the standard methods described in the manual. The programme number (630) for suspended solids was entered and the wavelength was adjusted to $810 \mathrm{~nm}$. A blank of 25 $\mathrm{ml}$ deionized water was measured into the sample cell and placed into the cell holder. The light shield was closed. The zero key was pressed, and the reading displayed $0.00 \mathrm{mg} / \mathrm{L}$. The blank was then removed, 25 $\mathrm{mL}$ of water was measured using the sample cell bottle and placed into the cell holder and the light shield closed. The READ/ENTER key was pressed and the SS value read directly in $\mathrm{mg} / \mathrm{L}$. The test was performed twice on each sample and average values recorded.

\subsubsection{Determination of Total Dissolved Solids (TDS):}

Total dissolved solid was determined with a TDS meter (Model 50150 from HACH Company). The probe was rinsed with distilled water followed by the water sample to be tested. The rinsed probe was allowed to stabilize in the sample for $1 \mathrm{~min}$ after which the TDS value was read directly in $\mathrm{mg} / \mathrm{L}$. The test was performed in duplicates on all the samples and average values recorded.

\subsubsection{Determination of Temperature}

EUTECH Instruments digital $\mathrm{pH}$ meter was used for the test.

\subsubsection{Determination of $\mathrm{pH}$}

The EUTECH Instruments digital pH meter was used. The meter was calibrated using different buffer solutions of $\mathrm{pH} 12.1,10.1,7.0$ and 4 . The electrode was immersed in the water sample and the steady value of $\mathrm{pH}$ read. Readings were taken in duplicates and average values recorded.

\subsubsection{Determination of Total Hardness}

The Hardness test Kit Model HA -4P-MG-L was used. Five $\mathrm{mL}$ of water sample was measured using a plastic tube and poured into the mixing bottle, 3 drops of buffer hardness solution was added and swirled to mix. One drop of ManVer hardness indicator solution was added. Ethylene diamine tetra acetic acid (EDTA) titrant was added, drop by drop into the mixing bottle and the mixture swirled, to allow for uniform mixing as each drop of the EDTA solution was added until a change in colour of the mixture from pink to blue was observed. The hardness in $\mathrm{mgL}^{-1}$ as calcium carbonate $\left(\mathrm{CaCO}_{3}\right)$ was calculated by multiplying the number of drops added by a factor of 20.The test was performed twice on each sample and average values recorded.

\subsubsection{Determination of Iron}

The FerroVer method described in HACH model DR/2000 spectrophotometer manual was used for the test. The meter was first adjusted to $\mathrm{mg} / \mathrm{Fe} \mathrm{Fv'.} \mathrm{A}$ sample cell (the blank) was filled with $25 \mathrm{~mL}$ of deionized water and placed in the cell holder and the display adjusted to $0.00 \mathrm{mg} / \mathrm{L} \mathrm{Fe} \mathrm{Fv}$. Another sample cell was then filled with $25 \mathrm{~mL}$ of the sample and the contents of one FerroVer reagent powder pillow added and swirled to mix. The prepared sample was then placed in the cell holder and the light shield closed. This displayed the results in $\mathrm{mg} / \mathrm{L} \mathrm{Fe}$. The test was done twice on each sample and mean values recorded.

\subsubsection{Determination of Manganese}

The Periodateoxidate method described in $\mathrm{HACH}$ DR/2000 spectrophotometer manual was used to determine the manganese (Mn) concentration. The meter was first adjusted to manganese periodateoxidate. The contents of one buffer powder pillow, citrate type and one sodium periodate powder pillow were added to a cell filled with $25 \mathrm{~mL}$ of test sample and swirled to mix. A blank was placed in the cell holder and the meter adjusted to ' $0.00 \mathrm{mg} / \mathrm{L} \mathrm{Mn} \mathrm{H'.}$ The prepared sample was then placed in the cell holder and the light shield closed and the displayed results in 'mg/L Mn' read. The test was performed twice on each sample and average values recorded. 


\subsubsection{Determination of Total Coliform Bacteria}

This was determined using the Most Probable Number (MPN) approach according to [15]. $10 \mathrm{~mL}$ of MacConkey broth were poured each in 15 bottles using sterile syringe. Inverted Durham tubes were inserted in each of the bottles. The bottles were then covered and autoclaved for 15 minutes at $121^{\circ} \mathrm{C}$. They were then removed and placed in a sterile environment. 10 $\mathrm{mL}$ of the water sample was inoculated in the first five bottles. One $\mathrm{mL}$ of water sample was inoculated in the second five bottles, while $0.1 \mathrm{~mL}$ of water was inoculated in the last five bottles. The bottles were kept in an incubator and observed at the end of 48 hours. The number of positive bottles, indicated by colour change and gas formation in each of the rolls was recorded and the bacteria load determined from the Most Probable Number (MPN) table.

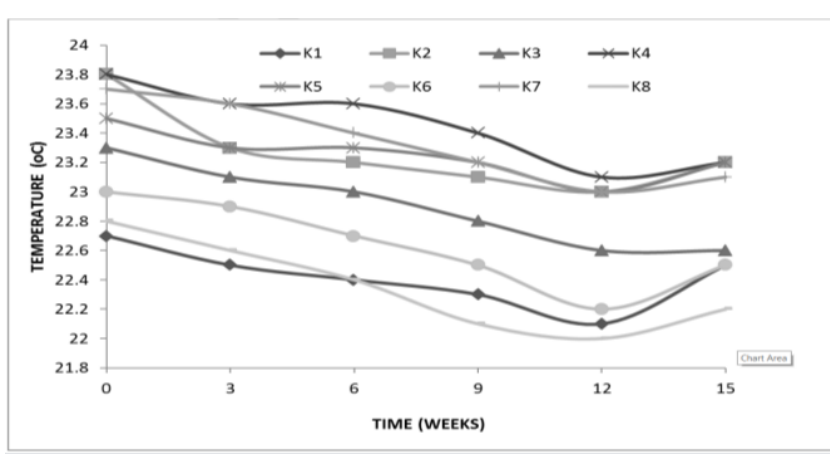

Figure 1: Temperature Values of sachet water in 15 weeks period

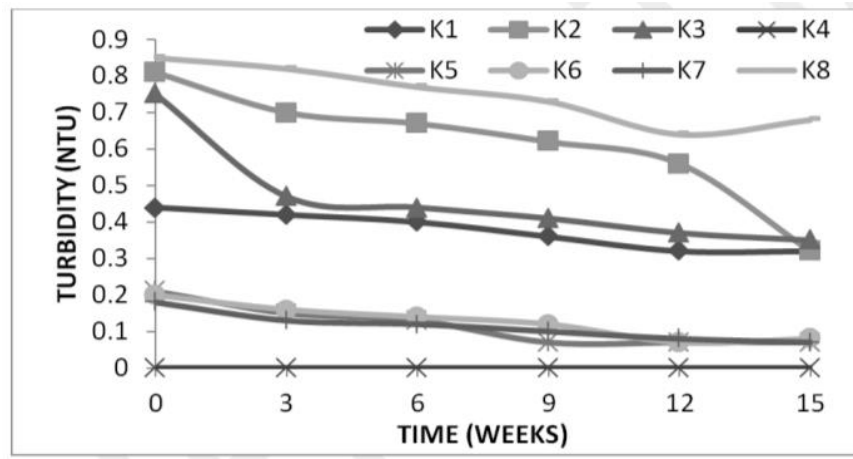

Figure 3: Turbidity of Sachet Water as a function of Time

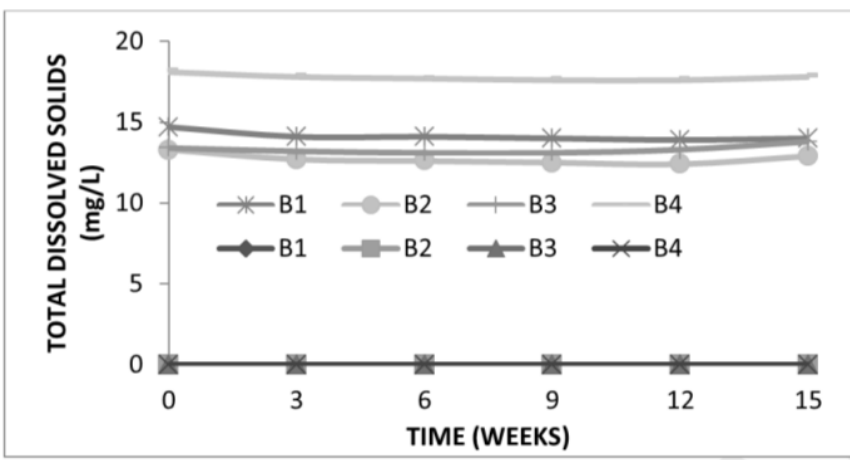

Figure 5: Total Dissolved Solids of Bottled water as a function of Time

\subsubsection{Determination of E.coli}

15 g of Cystine - Lactose - Electrolyte Deficient Medium (CLED) was dissolved in 1 litre of distilled water in a conical flask and autoclaved at $121^{\circ} \mathrm{C}$ for 15 minutes and allowed to cool. The top of the conical flask was wrapped with foil to prevent contamination. The experiment was done in a sterile environment. The prepared CLED was dispensed into petri dish and allowed to set. One $\mathrm{mL}$ of the water sample was inoculated on the prepared CLED and kept in an incubator for 48 hours at $37^{\circ} \mathrm{C}$. Yellow, opaque colonies with slightly deeper coloured centre about $1.25 \mathrm{~mm}$ diameter were identified, counted and recorded.

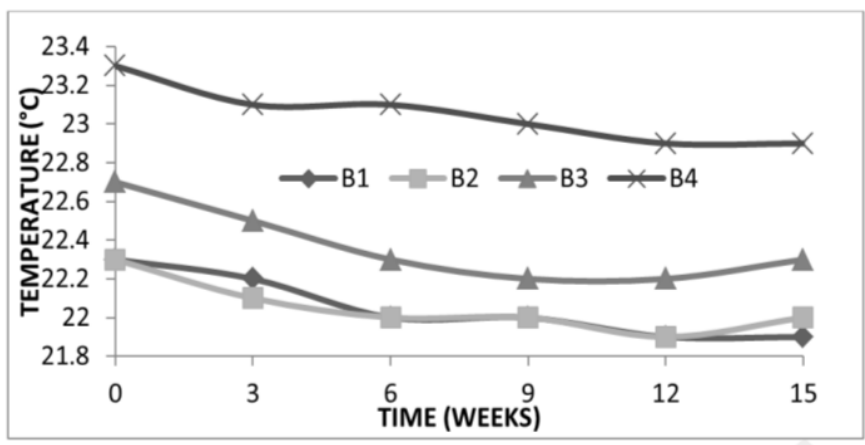

Figure 2: Temperature values of bottled water in 15 weeks period

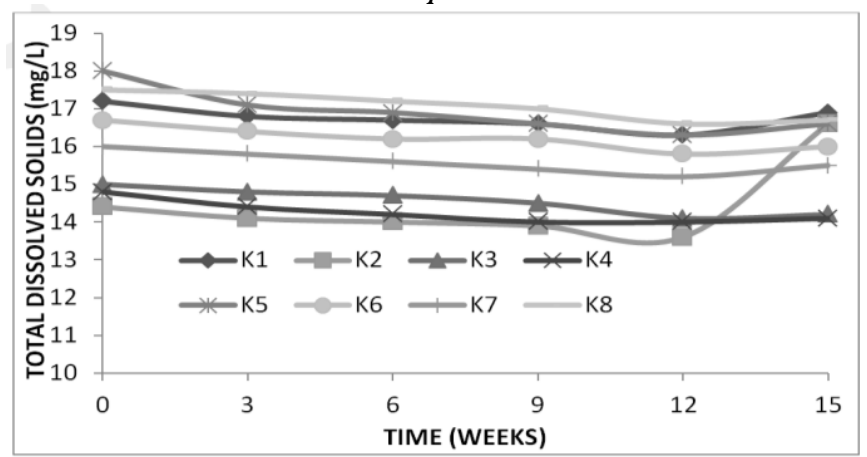

Figure 4: Total Dissolved Solids of Sachet Water as a function of Time

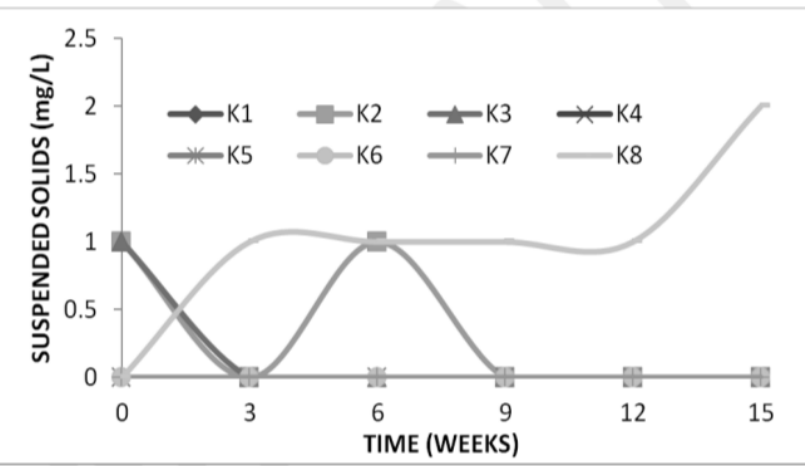

Figure 6: Total Suspended Solids Concentration of Sachet Water as a function of Time 


\section{RESULTS AND DISCUSSIONS}

The temperature of the sachet and bottled water samples ranged from $22^{\circ} \mathrm{C}-23.8^{\circ} \mathrm{C}$ (Figures 1 and 2). Variations in temperature were observed in all the samples, which may be attributed to the storage condition as suggested by [16]. The temperature fall within the optimal growth range for mesophilic bacteria, including human pathogens throughout the period of investigation.

The mean turbidity values for the sachet water samples ranged between 0-0.85 NTU (Figure 3) while all the bottled water samples recorded 0.00 NTU value for turbidity. This implies that all samples were within the [17] standard of 5.0 NTU set for Drinking water. The low values of turbidity measured are in line with the physical observation of the samples which revealed clear and colourless samples, without particulate matter.

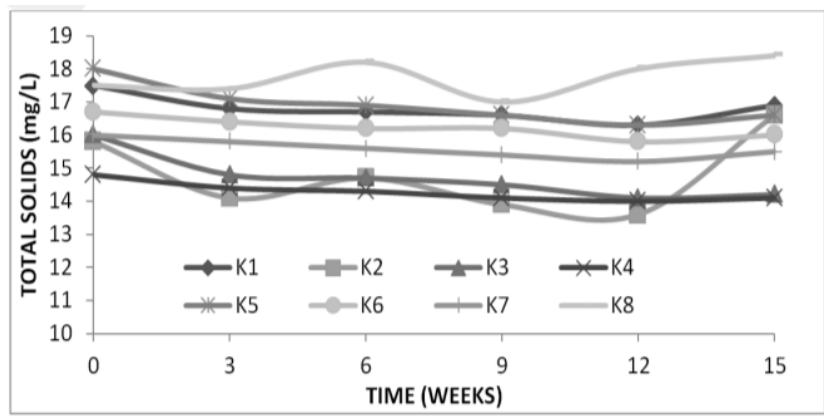

Figure 7: Total Solids of Sachet Water as a function of Time

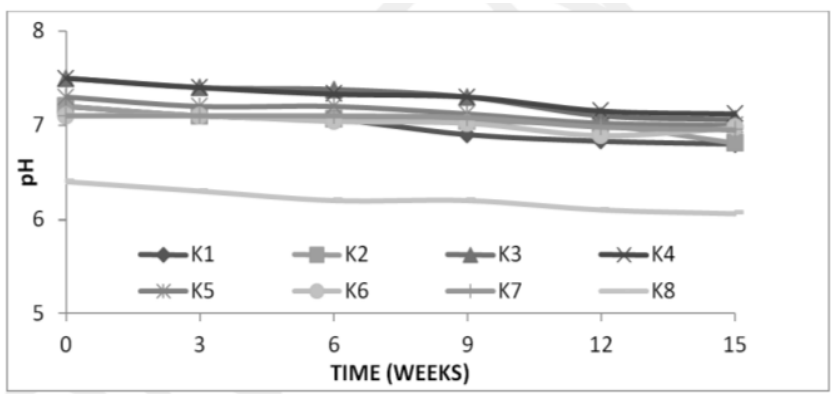

Figure 9: $p H$ Values of Sachet Water as a function of Time

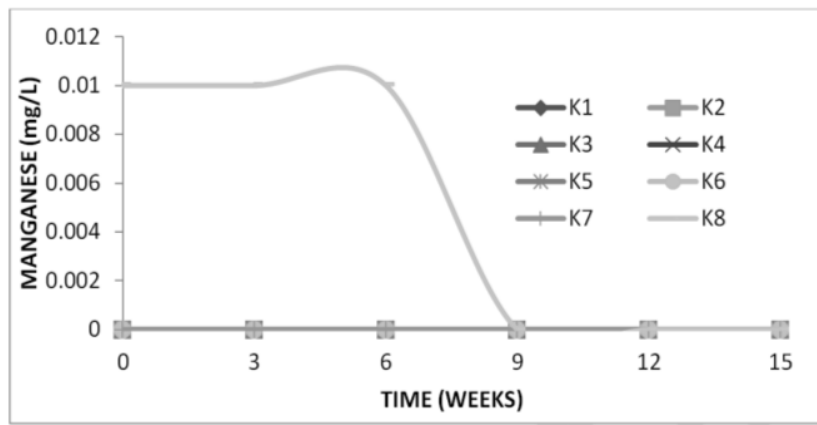

Figure 11: Manganese Concentration of Sachet Water as a function of Time
The Total Dissolved Solids (TDS) values recorded ranged between $13.60-18.10 \mathrm{mg} / \mathrm{L}$ for sachet water samples and $12.40-18.10 \mathrm{mg} / \mathrm{L}$ for bottled water samples (Figures 4 and 5). These were within the WHO standard of not more than $500 \mathrm{mg} / \mathrm{L}$ for drinking water. This further suggests that the water will not have laxative effects on consumers because the TDS is less than $2000 \mathrm{mg} / \mathrm{L}$ [18]. However, low TDS water consumption in humans could lead to some health challenges such as goiter, hypertension, ischemic, heart disease, etc., especially, in the presence of poor dietary habits [19].

Total suspended solids (TSS) values were generally low in all the samples. All the bottled water samples recorded $0.00 \mathrm{mg} / \mathrm{L}$ which is the WHO recommended standard. However, as shown in Figure 6, some of the sachet water samples namely; K2, K3 and K8 did not fall within the WHO limits, K8 recorded a maximum value of $2 \mathrm{mg} / \mathrm{L}$ at the $15^{\text {th }}$ week.

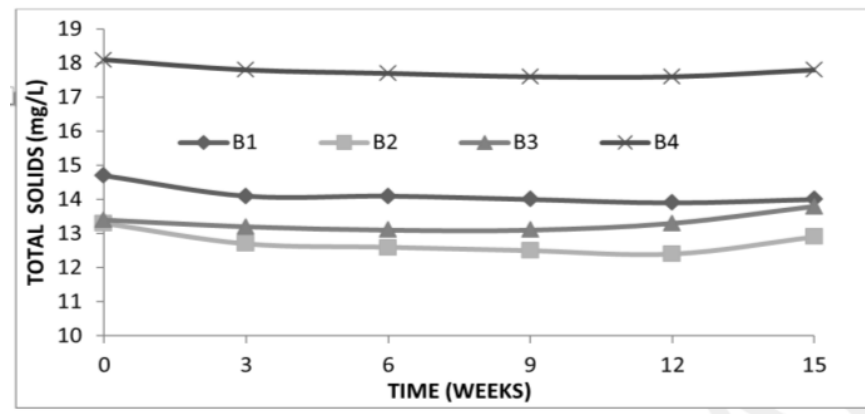

Figure 8: Total Solids in bottled Water as a function of Time

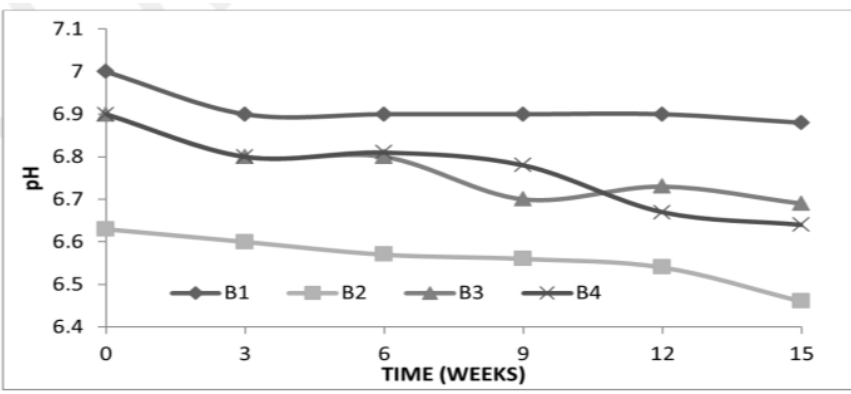

Figure 10: pH Values of bottled Water as a function of Time.

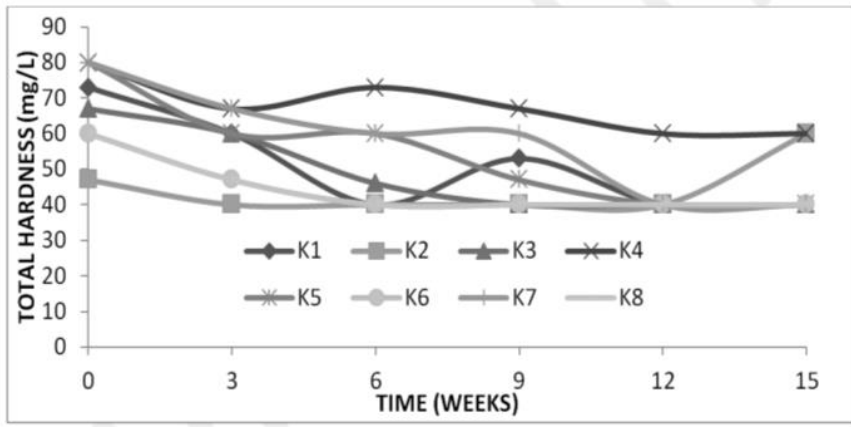

Figure 12: Total Hardness Concentration of Sachet Water as a function of Time

Vol. 37, No. 1, January 2018 
Throughout the period of the investigation, total solids (TS) for all samples examined were within the WHO recommended value of $1000 \mathrm{mg} / \mathrm{L}$. The maximum value obtained for sachet water was $18.4 \mathrm{mg} / \mathrm{L}$ while that of bottled water was $18.1 \mathrm{mg} / \mathrm{L}$ (Figures 7 and 8).Total solids is the sum of TDS and TSS. It is obvious that TDS, which is in dissolved form, contributed higher proportion of the TS compared to TSS, given that the concentration of TSS was generally low in all the samples.

$\mathrm{pH}$ values of sampled sachet and bottled water were presented in Figures 9 and 10. All the samples gave $\mathrm{pH}$

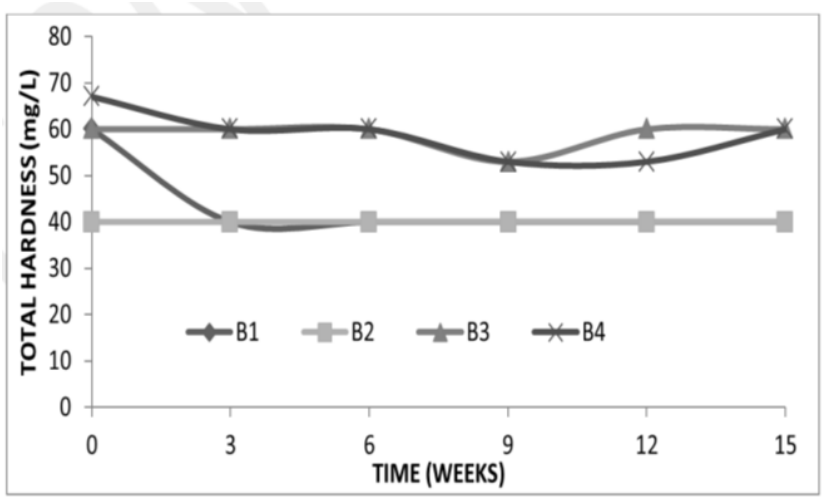

Figure 13: Total Hardness Values of bottled Water in 15 week period

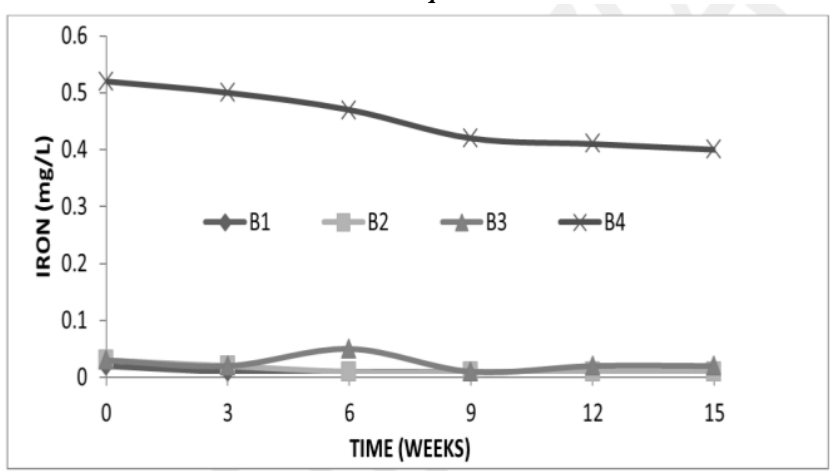

Figure 15: Iron Concentration of Bottled Water as a function of Time.

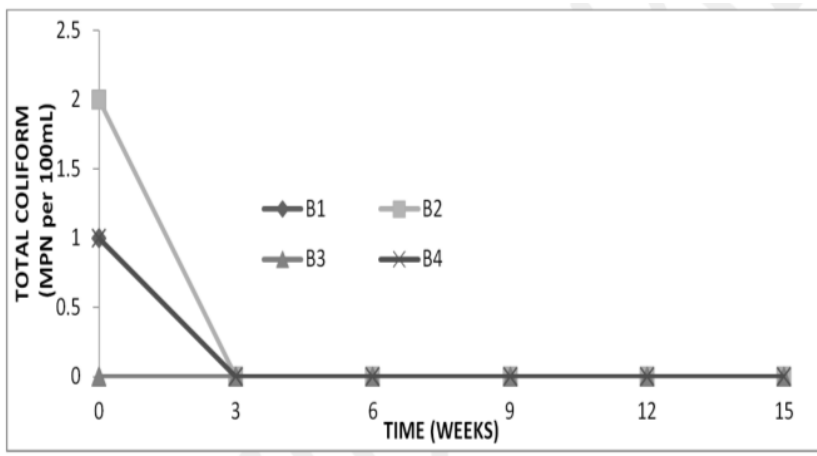

Figure 17: Total Coliform Values of Bottled Water in 15 week Period values within the recommended limits of 6.5- 8.5 for drinking water [17] indicating that they are safe for human consumption except sample K8 which was below the limits (slightly acidic). The highest value observed in sachet water was 7.50 in samples $\mathrm{K} 3$ and $\mathrm{K} 4$ on the first day of the test while the least value observed in sachet water was 6.06 in sample K8 in the $15^{\text {th }}$ week. In the bottled water samples, all the samples were within the WHO recommended range throughout the investigation period.

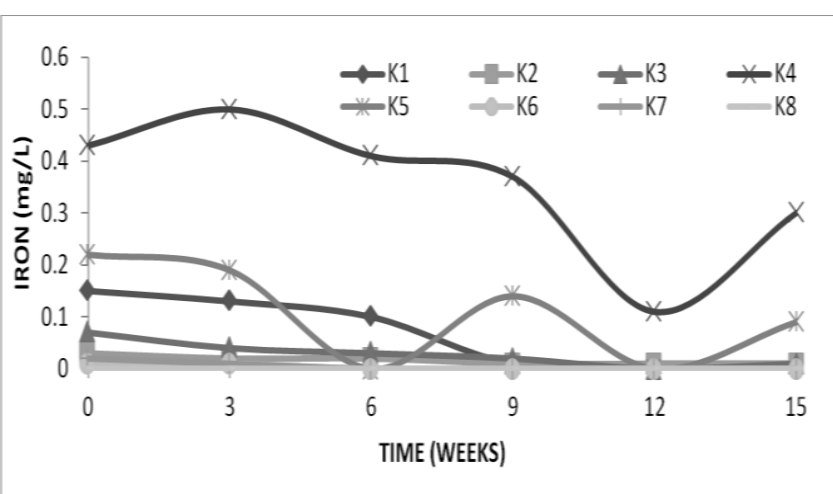

Figure 14: Iron Concentration of Sachet Water as a function of Time

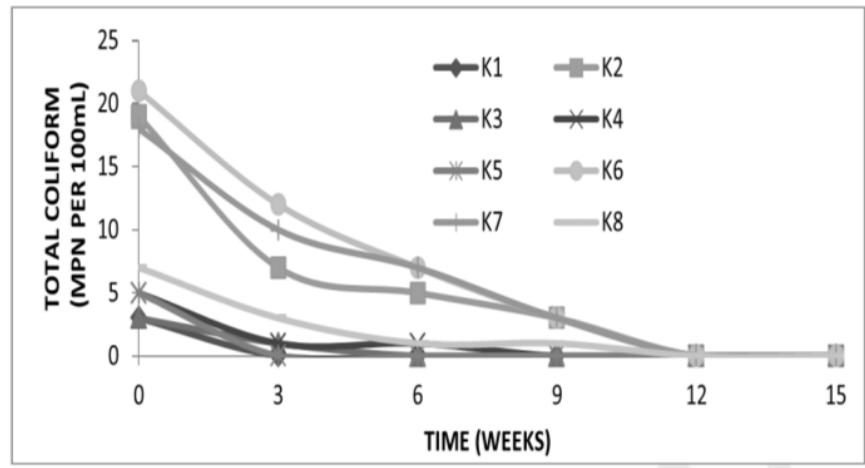

Figure 16: Total Coliform Values in Sachet Water in 15 week period.

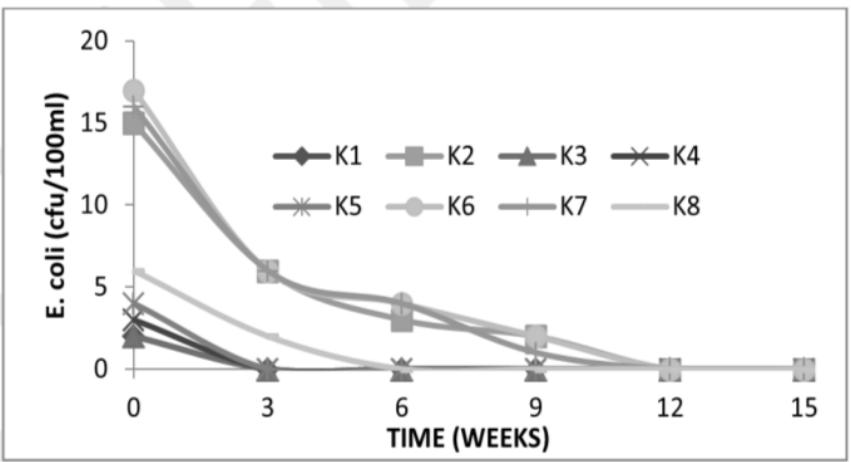

Figure 18: E. coli Values of Sachet Water as a Function of time. 
The entire bottled water samples had manganese concentration of $0.00 \mathrm{mg} / \mathrm{L}$. The concentration of manganese in sachet water as presented in Figure11 was also within WHO standard for manganese in drinking (0.00- $0.01 \mathrm{mg} / \mathrm{L})$. This indicates that, all samples were safe for consumption in terms of manganese content. The total hardness of the sachet water samples ranged from $40-80 \mathrm{mg} / \mathrm{L}$, while that of bottled water samples were within the range of 40-60 $\mathrm{mg} / \mathrm{L}$ (Figures12 and 13). These were within the WHO limit of $500 \mathrm{mg} / \mathrm{L}$ for drinking water.

With respect to iron content, all the sachet water samples showed the presence of iron except sample K8 which had $0.00 \mathrm{mg} / \mathrm{L}$. All samples were within the WHO limit of $0.30 \mathrm{mg} / \mathrm{L}$ for drinking water, except sample K4 which had iron concentrations of $0.37-0.50 \mathrm{mg} / \mathrm{L}$ (see Figure 14). Bottled water samples were also all within the WHO limit, except sample B4 which had a very high value of $0.52 \mathrm{mg} / \mathrm{L}$ (see Figure 15). It follows that samples $\mathrm{K} 4$ and B4 were not safe for consumption because they indicated a very high presence of iron. The high iron content may be because, the treatment process does not involve iron removal given that, both K4 and B4 are from the same source.

In terms of microbial quality, both sachet and bottle water sold in Gboko exhibited variable characteristics. The Total coliform count was very high in the sachet water on the first day of production, the least count was in samples $\mathrm{K} 1, \mathrm{~K} 3, \mathrm{~K} 4, \mathrm{~K} 5$ and $\mathrm{K} 8$, which was 3, 3, 5,5 and 7 MPN per $100 \mathrm{~mL}$ respectively, while the highest count was in K2, K6 and K7, which was 19, 21 and 18 MPN per $100 \mathrm{~mL}$ respectively. Packaged water consumed in some parts of Oyo State also contained bacteria as reported by [8]. Similar result was reported by [13] in a study on the quality of packaged water in Uyo metropolis, Nigeria. This contamination is traceable to improper disinfection or use of contaminated sachets for packaging. In bottled water, samples B1, B2 and B4 showed little traces that disappeared completely by the 12 th week, but sample B3 was completely free from bacteria (Figures 16 and 17).

High values of $E$. coli counts were recorded on the first day of production of sachet water. Samples K1 and K3 had $2 \mathrm{cfu}$, which was the least number. Samples K4, K5 and K8 had 3, 4 and 6 cfu respectively. Samples K6 and $\mathrm{K} 7$ recorded the highest values of $17 \mathrm{cfu}$ and $16 \mathrm{cfu}$ respectively (Figure 18). This finding suggests that, some sachet water products produced and consumed in Gboko are not safe for drinking before 12 weeks after production Figure 19 show that all the bottled water samples had $1 \mathrm{cfu}$ except sample B3 that showed no trace of E.coli in it. It was observed that after three weeks of storage, the bacteria completely disappeared in all the bottle water samples but still showed traces in some of the sachet water sample such as K2, K6, K7 and K8 up to the $9^{\text {th }}$ week but completely disappeared in the $12^{\text {th }}$ week. This observation is in line with [15] report that indicator organism's loose viability in fresh water environment with time. However, [10] reported proliferation of bacteria in sachet water in Port Harcourt when stored beyond 4 weeks.

In general, the bottle water brands were of better microbial quality compared to sachet water similar to [20] findings that larger proportion of sachet water showed positive coliform counts compared to bottled water sold in Ibadan town. Contamination of packaged drinking water may result from the raw source of water, treatment employed and handling during production. The results of the microbial tests revealed that, it is better to store sachet and bottled water in Gboko for 12 and 3 weeks respectively after production, before consumption, to avoid the risk of bacterial contamination.

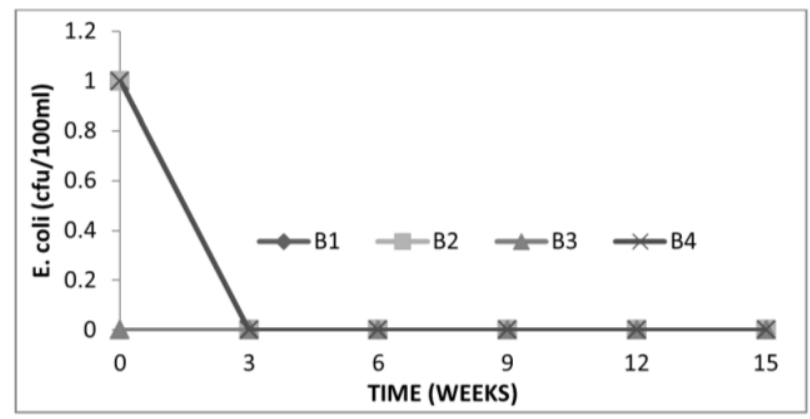

Figure 19:E.coli Values of Bottled Water as a Function of time

\section{CONCLUSIONS}

The field sampling and laboratory analysis of sachet and bottled water in Gboko metropolis reveals that all the samples analysed were satisfactory in terms of physical characteristics, in the sense that they all met the WHO recommended standard for drinking water in terms of colour, odour, temperature, turbidity, total dissolved solids, total suspended solids and total solids and could be consumed for as long as 15 weeks if stored at room temperature. With respect to chemical characteristics, all the sachet and bottled water samples met the WHO recommended standard for manganese and total hardness in drinking water. Sample K4 and B4 (Wishden sachet and bottled water) showed very high content of iron which is far greater 
than the WHO recommended value for iron in drinking water.

In terms of the microbial characteristics, most of the sachet water samples contained coliform bacteria and E.coli, which disappeared by the 12 week of storage. The bottled water samples became free of bacteria after 3 weeks of storage, hence is safe for human consumption after 3 weeks of production. It was recommended that sachet and bottled water, produced and consumed in Gboko can be used after 3 weeks (in the case of bottle water) and 12 weeks (in the case of sachet water) of production respectively, and the water is safe up to 15 weeks after production. However, there is need to investigate the Self life beyond 15 weeks to determine the actual Shelf life which may be more than 15 weeks, based on the results of this research.

\section{REFERENCES}

[1] Ford, T. E. Microbiological Safety of Drinking Water, United State and Global Perspective Environmental Health perspective (suppl.1), , pp 191-206 1999,

[2] Deborah, C. Water Quality Assessment: A guide to use of Biota, Sediments and Water in Environmental monitoring, $2^{\text {nd }}$ Edition. UNESCO/UNEP/WITO, pp1-117, 1999.

[3] Warren, V. and Mark, J. H. Water Supply and Pollution Control: A Guideline for Drinking Water Quality. Addison Wesley Longman Inc, California, 1998.

[4] Ukpng, E. C and Peter B. U. " Physico-chemical and bacteriological Analysis of Drinking Water in Ibeno Local Government of Akwa Ibom State, Nigeria" Nigerian Journal of Technology, Vol. 31, No. 2, pp. 116 - 127, 2012.

[5] Sojobi, A. O., Owamah, H. I. and Dahunsi, S. O. "Comparative Study of Household Water Treatment in a Rural Community in Kwara State, Nigeria", Nigerian Journal of Technology, Vol. 33, No. 1, pp. $134-140,2014$.

[6] Dada, A. C.; and Ntukekpo, D. S. "Pure water: how safe? "Ultimate Water Technology and Environment, Vol.1, Number 3, pp 8-11, 1997.

[7] Ezeugwunne, I. P.; Agbakoba, N. R.; Nnamah, N. K. and Anahalu, I. C. "The prevalence of bacteria in packaged sachets water sold in Nnewi, South East, Nigeria", World Journal of Dairy \& Food Sciences, Vol. 4, Number 1, pp 19-21, 2009.

[8] Ajayi, S.; Osibanjo, O.; and Akinyanju, P. Public Analysis: Reporting Systems as Applied to Environmental issues. IPAN News, A. Publication of the Institute of Public Analysts, 1(3), p 10, 2008.
[9] Uduma, A. U. and Maria, B. U. "Physicochemical analysis of the quality of sachet water consumed in Kano metropolis", American Journal of Environment, Energy and power Research. Vol.2, Number1, 2014, pp 1-10.

[10] Akinde, S. B.; Nwachukwu, M. I.; and Ogamba, A. S. "Storage Effects on the Quality of Sachet Water Produced within Port Harcourt Metropolis Nigeria.", Journal of Biological Sciences, Vol. 4, pp157-164, 2011.

[11] Onifade, A. K. and Ilori, R. M. "Microbiological Analysis of Sachet Water Vended in Ondo State, Nigeria", Environmental Research Journal, Vol. 2, pp. 107-110, 2008.

[12] Adekunle, L.V.; Sridhar, M. K. C.; Ajayi, A. A.; Olawuyi, P.A.; and Olawuji, J. F. "An Assessment of the Health and Social Economic Implications of Sachet Water in Ibadan Nigeria: A Public Health Challenge", African Journal of Biomedical Research, Vol. 7, pp 5-8, 2004.

[13] Odiongenyi, A. O., Okon, J. O. J, and Enengedi, I. "Assessment of Quality of Packaged Water in Uyo Metropolis, South Eastern Nigeria", International Journal of Chemical Materials and Environmental Research, Vol.2, Number 1, , pp 12-15, 2015.

[14] Yusuf, Y. O. Jimoh, A. I., Onaolapo, E. O. and Dabo, Y. "An Assessment of Sachet Water Quality in Zaria Area of Kaduna State, Nigeria”, Journal of Geography and Regional Planning, Vol.8, Number7, pp 174-180, 2015.

[15] APHA, Standard Methods for the Examination of Water and Wastewater, 20th Edition, American Public Health Association, Washington D. C., 1998.

[16] Waziri, F. M. and Bomai, A. M. "The PhysicoChemical Quality of Sachet Water in Damaturu, Yobe State, Nigeria", International Journal of Basic and Applied Chemical Sciences, Vol. 2, Number 3, pp 21-24, 2012.

[17] WHO Guidelines for Drinking Water Quality. 4th edition, World Health Organization, Geneva, 2011.

[18] Oteze, G. E. "Portability of Ground water of the Rima group of Aquifers in the Sokoto Basin", Nigeria Journal of Geology and Mining, Vol. 27, Number 1, pp17-21, 1991.

[19] Akpoborie, I. A. and Ehwarimo, A. "Quality of Packaged Drinking Water Produced in Warri Metropolis and Potential Implications for Public Health", Journal of Environmental Chemistry and Ecotoxicology, Vol.4, Number 11, pp 195-202, 2012.

[20] Ajayi, A. A, Sridhar, M. K. C. Adekunle, L.V. and Oluwande, P. A. "Quality of Packaged Waters Sold in Ibadan, Nigeria", African Journal of Biomedical Research, Vol. 11, pp 251-258, 2008. 